\title{
INTERNATIONAL ASSOCIATION OF UNIVERSITY PROFESSORS AND LECTURERS (IAUPL) ASSOCIATION INTERNATIONALE DES PROFESSEURS ET MAITRES DE CONFERENCES DES UNIVERSITES
}

\author{
21 , rue Isabey \\ 5400 Nancy (France) \\ Tel: (83) 28-1221 \\ Standing Secreteriat: \\ 18, rue du Docteur Roux \\ 75015 Paris
}

Tel: (33-1) 4783-3165

Secretary-General: L.P. Laprévote

IAUPL is a non-governmental, non-political, non-sectarian body. It is recognized as holding consultative status by Unesco, and by other United Nations organizations. It is a democratically constitued federal organization of the separate national associations of university teachers, and in some cases of the separate associations of teachers in single universities, who thereby collaborate in the international sphere. IAUPL comprises affiliated associations and individual members representing a total membership in seventeen countries. The broad aims of IAUPL are the development of academic fraternity among university teachers of the various countries across national and faculty boundaries; the protection of the independance and freedom of teaching and research; the furtherance of the interests of university teachers; and the consideration of academic problems, wether initiated by the Association itself or referred to it by governments or universities or by Unesco. In 1982, IAUPL adopted a charter of rights and obligations of university teachers (Siena). Topics of interest to all university teachers are discussed at international conferences.

A "European Liaison Committee", set up in 1973, has held several meetings in Paris, Germany, Brussels, Rotterdam, and London at which problems of particularrelevance to Europe have been discussed with the collaboration of European organizations (Council of Europe, EEC).

Principal publications: The Status of
University Teachers; The Recruitment and Training of University Teachers.

L'IAUPL est un organisme non-gouvernemental, apolitique et non-confessionnel. Elle bénéficie du statut consultatif auprès de l'Unesco et d'autres institutions des Nations unies. L'association est une organisation fédérale démocratiquement constituée d'associations nationales d'enseignants universitaires et, dans certains cas, d'associations d'enseignants existant au sein d' universités individuelles, qui collaborent ainsi à l'échelon international. L'IAUPL comprend des associations adhérentes et des membres individuels dans 17 pays. Les grands objectifs de l'IAUPL sont le développement de la fraternité académique entre enseignants universitaires par-delà les frontières des différents pays, des nations et des facultés, la sauvegarde de l'indépendance et de la liberté de l'enseignement et de la recherche, la défense des intérêts des enseignants universitaires et l'examen des problèmes universitaires, soit à l' initiative de l'Association elle même, soit à la demande de gouvernements, d'universités ou de l'Unesco. Elle entretient une collaboration amicale avec les organisations analogues se consacrant à d'autres aspects du travail et de la vie universitaires. Ces sujets et d'autres d'intérêt commun à tous les enseignants universitaires sont débattus à des conférences internationales.

Depuis 1973 fonctionne un "Comité de Liaison Européen" dont plusieurs réunions à Paris,en Allemagne, à Bruxelles, à Rotterdam et à Londres ont traité de problèmes plus spécialement européens avec la collaboration d'organisations européennes (Conseil de l'Europe, CEE).

Publications principales: "The Status of University Teachers"; "The Recruitment and Training of University Teachers". 